\title{
Unrelated secondary reproductives in the neotropical termite Silvestritermes euamignathus (Isoptera: Termitidae)
}

\author{
Ives Haifig ${ }^{1,2,3}$ • Edward L. Vargo ${ }^{3,4} \cdot$ Paul Labadie $^{3}$. \\ Ana Maria Costa-Leonardo ${ }^{1}$
}

Received: 30 July 2015 /Revised: 14 December 2015 / Accepted: 18 December 2015 /Published online: 19 January 2016

(C) Springer-Verlag Berlin Heidelberg 2016

\begin{abstract}
A termite colony is usually founded by a pair of alates, the primary reproductives, which produce all the nestmates. In some species, secondary reproductives appear to either replace the primaries or supplement colony reproduction. In termites, secondary reproductives are generally ergatoids derived from workers or nymphoids derived from nymphs. Silvestritermes euamignathus is a termite species that forms multiple nymphoid reproductives, and to date it was hypothesized that these secondary reproductives were the progeny of the primary founding reproductives. We developed markers for 12 microsatellite loci and used COI mitochondrial DNA (mtDNA) to genotype 59 nymphoid neotenics found in a colony of $S$. euamignathus to test this hypothesis. Our results showed that nymphoids of $S$. euamignathus are not all siblings. The microsatellite analysis suggests that the secondary reproductives derived from a minimum of four different pairs of reproductives belonging to at least two different matrilines. This is the first record of non-sibling secondary reproductives
\end{abstract}

Communicated by: Sven Thatje

Ives Haifig

haifig@ufu.br

1 Laboratório de Cupins, Departamento de Biologia, Instituto de Biociências, Univ Estadual Paulista-UNESP, Campus Rio Claro, Avenida 24A, 1515, Bela Vista, Rio Claro, SP 13506-900, Brazil

2 Current address: Instituto de Ciências Agrárias, Universidade Federal de Uberlândia-UFU, Campus Monte Carmelo, Avenida Goiás, 2000, Vila Nova, Monte Carmelo, MG 38500-000, Brazil

3 Department of Entomology, North Carolina State University-NCSU, Campus Box 7613, Raleigh, NC 27695-7613, USA

4 Current address: Department of Entomology, 2143 TAMU, Texas A\&M University, College Station, TX 77843, USA occupying the same nest in a higher termite. These unrelated reproductives might be the result of either pleometrotic colony foundation or colony fusion.

Keywords Microsatellites $\cdot$ mtDNA $\cdot$ COI $\cdot$ Genotyping · Neotenics

\section{Introduction}

Termites exhibit one of the most fascinating reproductive systems among the social insects. These insects present an incredible plasticity of castes participating in reproduction, from regular primary reproductives derived from alates to ergatoid reproductives derived from workers (Noirot 1956; Myles 1999), reproductive soldiers in Zootermopsis (Thorne et al. 2003), nymphoid neotenics derived from nymphs (Noirot 1956; Myles 1999), and the parthenogenetically-produced nymphoids in lower and higher termites, which succeed the queen (Matsuura et al. 2009; Vargo et al. 2012; Luchetti et al. 2013; Fougeyrollas et al. 2015). Primary reproductives are winged imagos and the ancestral reproductive forms, whereas ergatoids and nymphoids are, respectively, apterous and brachypterous neotenics, a novelty of termites.

According to the origin, relatedness, and number of active reproductives, termite colonies are classified as simple families, extended families, and mixed families (reviewed in Vargo and Husseneder 2011). Simple families are colonies headed by a regular monogamous pair, the royal couple, whereas extended and mixed families present multiple reproductives. When multiple neotenics appear to supplement or replace the founding queen, we classify such colonies as extended families, because both primary queen and neotenics contribute to the offspring, and all the individuals, with exception of the king, share the queen's mitochondrial DNA (mtDNA) 
haplotype and exhibit no more than four alleles at a single microsatellite locus. Families are extended even when the primary queen is already dead and all offspring is produced only by the neotenics.

When multiple female alates co-found a colony, we have a case of pleometrotic polygyny (Atkinson and Adams 1997; Hartke and Rosengaus 2013), and the colony is classified as a mixed family. Mixed families can also result from colony fusion (DeHeer and Vargo 2004, 2008). The offspring of a mixed family exhibit multiple allele combinations, and frequently more than four alleles at one or more microsatellite loci. Mixed families formed either by unrelated female alates or by colony fusion may also exhibit different matrilines, as occurs in Nasutitermes corniger (Atkinson and Adams 1997), Macrotermes michaelseni (Hacker et al. 2005), and Reticulitermes flavipes (DeHeer and Vargo 2004, 2008). In both extended and mixed families, the multiple females may be accompanied by multiple males, because polyandry is often associated with polygyny in termites (Roisin and Pasteels 1985).

Silvestritermes euamignathus is a neotropical higher termite species that occurs predominantly in open vegetation, from southern Brazil to northern Venezuela (Rocha et al. 2012). This species presents nasute-mandibulate soldiers and builds epigeal nests of variable forms, most commonly exhibiting a dome form (Mathews 1977; Coles-de-Negret and Redford 1982). Replacement reproductives are relatively rare in higher termites when compared to lower termites (Miller 1969; Noirot 1969; Myles 1999), and genetic studies analyzing these individuals are equally scarce in higher termites. Costa-Leonardo et al. (1996) found multiple male and female nymphoid reproductives in one nest of this species without either primary reproductives and in two other nests containing only the king. Later, the authors were able to artificially reproduce this scenario by experimentally orphaning natural colonies (Costa-Leonardo et al. 1998). In their study, Costa-Leonardo et al. (1998) stated that most nests of S. euamignathus presented the royal couple and neotenics were absent. Morphological analysis of the neotenics suggested their active participation in reproduction (CostaLeonardo et al. 1999), and it was hypothesized that the naturally occurring secondary reproductives found by CostaLeonardo et al. (1996) were full siblings that differentiated upon the death of the primary queen. The occurrence of multiple neotenics in colonies of $S$. euamignathus makes this termite species a good candidate to investigate the genetic relationship within these individuals.

In this study, we investigated the relationship of multiple nymphoid neotenics found in a colony of $S$. euamignathus. We developed markers for 12 microsatellite loci to assess the genetic variation within the reproductives, and used COI mtDNA genotyping as a supplemental technique to determine the number of matrilines present in a colony. We tested the hypothesis by Costa-Leonardo et al. (1996) about the relationship within neotenics, and where genetic diversity was higher than expected for simple families, the number of matrilines was used as support to elucidate the mechanism involved in the process.

\section{Material and methods}

Termites We collected five nests (colonies A-E) of S. euamignathus (Silvestri, 1901) in field areas at Rio Claro, SP, Brazil between September and November 2013. The nests were carried to the Laboratório de Cupins, UNESP campus, Rio Claro, SP. The nests were collected near to small fragments of natural Cerrado vegetation bordered by Eucalyptus plantations, frequently occurring in small ravines along the roads, or leaning tree trunks, but always easily detachable. They were collected along a range of $3 \mathrm{~km}$ distance (the highest distance between colonies $\mathrm{A}$ and $\mathrm{E}$ ), with the smallest distance of $50 \mathrm{~m}$ apart between colonies B and C. Samples of all castes and all of the reproductives found were collected. The samples were stored in $95 \%$ ethanol and sent to the Department of Entomology, North Carolina State University, Raleigh, NC, USA. One of these nests (colony D) contained 59 nymphoid neotenics: 27 males and 32 females, two of which being darker reproductives similar to alates in pigmentation, but with short wingbuds as in all the other neotenics (Fig. 1), whereas no reproductives were found in the other four colonies. All the nests shared the same shape and structure, the colonies were mature and exhibited nymphs or alates, but only the colony D containing the neotenics exhibited nymphs from all instars at the date of the collection.

\section{Microsatellite marker development}

DNA extraction for sequencing We extracted DNA from the heads of seven workers of $S$. euamignathus using a DNeasy

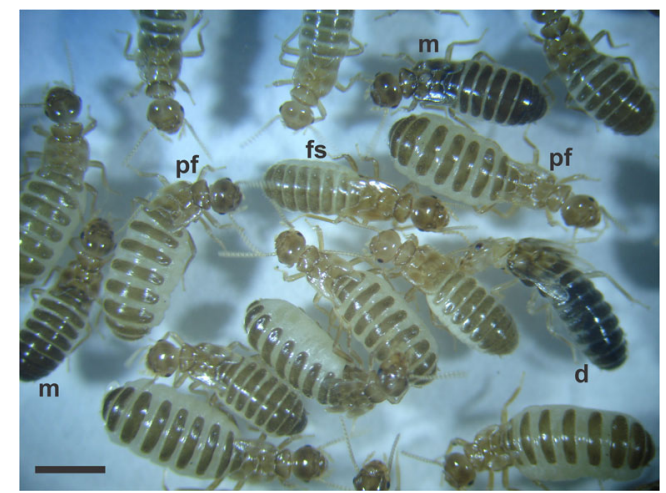

Fig. 1 Multiple nymphoid neotenics of S. euamignathus with differences in physogastry. $p f$ physogastric females, $f_{s}$ females with a swollen abdomen, $m$ male reproductive, $d$ darker reproductive. $B a r=500 \mu \mathrm{m}$ 
Blood \& Tissue kit (Qiagen ${ }^{\circledR}$ ) following the manufacturer's instructions. We used only termite heads to avoid contamination with the gut material and we pooled multiple individuals to obtain sufficient quantity of DNA for library preparation and sequencing.

DNA sequencing The Illumina MiSeq Reagent Kit V3 was used for the library preparation (300x300 Paired-end reads) and sequencing was performed using the Illumina MiSeq Sequencer. The sequencing generated approximately $22 \mathrm{M}$ 300-bp paired-end reads, which were de novo assembled using the program SparseAssembler (Ye et al. 2012). The output product consisted of consensus regions of DNA (contigs), which were used to screen for the microsatellites.

Selection of microsatellite markers The contigs were analyzed using the Msatcommander ${ }^{\circledR}$ program for detecting microsatellite loci. The search parameter was set for trinucleotide microsatellite loci, with output files showing the repeats. We designed 54 primer pairs for the sequences containing microsatellite loci using Primer 3 v. 4.0.0 software (Koressaar and Remm 2007; Untergrasser et al. 2012). An M13 oligonucleotide fragment (CACGACGTTGTAAAACGAC) was added to the $5^{\prime}$ end of each forward primer and was complementary to the LiCor IRDye-M13 fluorescent dye necessary for genotyping. The primers were optimized for PCR and the products of the reactions were analyzed on a Li-Cor 4300 automated DNA sequencer (Li-Cor, Inc., Lincoln, NE, USA). We used DNA from five samples, one individual from each colony, to select 12 polymorphic microsatellite markers for use in this study (Table 1). All the primers had an annealing temperature at $55^{\circ} \mathrm{C}$ and we were not successful in combining different loci in multiplex reactions.

Microsatellite genotyping A total of 100 workers, 20 from each colony, and the 59 neotenic reproductives found in colony D were genotyped for the 12 selected loci. PCR reactions were carried out in $6-\mu \mathrm{L}$ volumes, each containing $7 \mathrm{ng}$ of template DNA, $1 \times$ PCR buffer, $1.9 \mathrm{mM} \mathrm{MgCl} 2,0.25 \mathrm{mM}$ dNTPs, 1 pmol each primer (forward and reverse), 0.03 pmol M13F-29/IRD800 IRDye tag (Li-Cor, Inc), 0.05 U Taq DNA Polymerase (Bioline TaQ Polymerase BIO-21086) and $\mathrm{ddH}_{2} \mathrm{O}$. PCR products were separated by electrophoresis on $6 \%$ polyacrylamide gels run at a constant power of $40 \mathrm{~W}$ at $50{ }^{\circ} \mathrm{C}$ for $2 \mathrm{~h}$. The gel images were analyzed using GeneProfiler software (Scanalytics, Inc) to determine the allele sizes. All the alleles were an extra $19 \mathrm{bp}$ in length due to the M13 tail.

Data analysis The number of alleles per colony was obtained for each locus using the Excel add-in Microsatellite toolkit. We also estimated $F$-statistics and relatedness within colonies using FSTAT (Goudet 2002). For the FSTAT analysis we used the workers' genotypes.

\section{Mitochondrial DNA}

We used the DNA of the microsatellite-genotyped samples to run preliminary tests using three mitochondrial DNA genes: COI, COII and 16S. We used one sample from each colony to detect haplotype variation in the population. We selected the gene COI, which presented different haplotypes varying at eight positions. PCR reactions were carried out in $25-\mu \mathrm{L}$ volumes, each containing $50 \mathrm{ng}$ of template DNA, $1 \times$ PCR buffer, $1.75 \mathrm{mM} \mathrm{MgCl}_{2}, 0.1 \mathrm{mM}$ dNTPs, 0.1 pmol each primer (Forward-ATTCAACCAATCATAAAGATATNGG and Reverse-TATACTTCAGGGTGTCCGAAAAATCA), 0.07 U Taq DNA Polymerase (Bioline TaQ Polymerase BIO21086) and $\mathrm{dd}_{2} \mathrm{O}$. Cycling conditions were: initial denaturing at $95^{\circ} \mathrm{C}$ for $3 \mathrm{~min}$, followed by 35 cycles of $1 \mathrm{~min}$ denaturing at $95^{\circ} \mathrm{C}, 1: 30 \mathrm{~min}$ annealing at $45^{\circ} \mathrm{C}$ and 2 min extension at $72{ }^{\circ} \mathrm{C}$, and final step at $72{ }^{\circ} \mathrm{C}$ for $5 \mathrm{~min}$. Based on the microsatellite analysis, we selected 40 individuals, five from each colony (A, B, C, and E) and 20 from colony D, composed of seven workers, six female nymphoids, five male nymphoids, and two darker reproductives to be sequenced. The selection was based on variation in the 12 microsatellite loci and the chosen samples presented different allelic combinations. The mitochondrial analysis was performed to supplement the microsatellite genotyping and to test whether the observed genetic diversity was result of multiple mating of a single queen.

\section{Results}

\section{Microsatellite markers}

Within the colonies genotyped, A, B, C, and E presented from one to four alleles per locus, which is in agreement with the occurrence of colonies initiated by single parents. Mean values of expected (HE) and observed (HO) heterozygosities were $0.6299 \pm 0.0360$ and $0.7808 \pm 0.0255$, respectively. Colony $\mathrm{D}$ presented more than four alleles for nine out of the 12 loci (Table 2), indicating the presence of multiple unrelated reproductives in the colony. The neotenics presented a total of 72 different alleles among the 12 loci, and nine alleles were exclusively found among the females (Table 2). The different allelic combinations indicate the occurrence of at least three pairs of reproductives in the previous generation (with a maximum of four alleles per locus for each reproductive pair).

Overall, colonies were slightly inbred $\left(F_{\mathrm{IT}}=0.064 \pm 0.03\right.$ (SE)), with moderate differentiation among them $\left(F_{\mathrm{CT}}=0.25 \pm 0.014\right)$. Individuals were relatively outbred relative to others within their colonies $\left(F_{\mathrm{IC}}=-0.248 \pm 0.028\right)$, 
Table 1 Characteristics of 12 microsatellite markers developed for S. euamignathus

\begin{tabular}{|c|c|c|c|c|c|}
\hline Locus & Primer sequences & Repeat motif & $\mathrm{N}_{\mathrm{A}}$ & Size (bp) & $\begin{array}{l}\text { GenBank } \\
\text { accession } \\
\text { number }\end{array}$ \\
\hline $\mathrm{Sel}$ & F: GGAGACAGTAACATGGTGCC & $(\mathrm{AAC})_{8}$ & 8 & $104-143$ & KU358999 \\
\hline $\mathrm{Se} 2$ & $\begin{array}{l}\text { R: AGAGGTAAAAGGCAGAATGGGA } \\
\text { F: ACTGGTCACTCTGCTTCACA }\end{array}$ & $(\mathrm{AAT})_{8}$ & 12 & $224-272$ & KU359000 \\
\hline \multirow[t]{2}{*}{$\mathrm{Se} 3$} & $\begin{array}{l}\text { R: ACCACGGATCTACATTCTTTCC } \\
\text { F: TGAGAAGCCATTGTCCACCA }\end{array}$ & $(\mathrm{GTT})_{8}$ & 8 & $173-201$ & KU359001 \\
\hline & $\begin{array}{l}\text { R: TGAGATCGAAATTGCCACAGT } \\
\text { F: AGTGCAGGGATGTCAAACTG }\end{array}$ & $(\mathrm{ATC})_{9}$ & 7 & $163-258$ & KU359002 \\
\hline \multirow[t]{2}{*}{$\operatorname{Se} 5$} & $\begin{array}{l}\text { R: GGGCCTCATAACCTTGACCT } \\
\text { F: ACTGAACGAGTTGTCTGCAA }\end{array}$ & $(\mathrm{ATC})_{8}$ & 6 & $210-237$ & KU359003 \\
\hline & $\begin{array}{l}\text { R: GGTTTCTTCCATGACCACCA } \\
\text { F: GGAGGAGGACGAGGAAAAGG }\end{array}$ & $(\mathrm{AAG})_{11}$ & 12 & 199-307 & KU359004 \\
\hline Se6 & $\begin{array}{l}\text { R: TGCCGTGTATGGAGTTCAGT } \\
\text { F: ACCCTGAAACCGAAAACGTT }\end{array}$ & $(\mathrm{ACG})_{11}$ & 10 & $124-292$ & KU359005 \\
\hline $\mathrm{Se} 7$ & $\begin{array}{l}\text { R: ACCTCTTCCTTCAACAACAACA } \\
\text { F: TTGCTACTCCTGCCCTCATC }\end{array}$ & $(\mathrm{ATT})_{13}$ & 8 & $111-144$ & KU359006 \\
\hline $\mathrm{Se} 8$ & $\begin{array}{l}\text { R: GGGGATTACGCAAACCTTCG } \\
\text { F: GCTGAGAGAGTGGACTGGAC }\end{array}$ & $(\mathrm{ATT})_{8}$ & 9 & $173-215$ & KU359007 \\
\hline $\operatorname{Se} 9$ & $\begin{array}{l}\text { R: TTTCTCGGCTGCACTATTGT } \\
\text { F: CGGTGTGCATATTGTTTGAGC }\end{array}$ & $(\mathrm{ATC})_{9}$ & 4 & $129-138$ & KU359008 \\
\hline \multirow[t]{2}{*}{$\mathrm{Sell}$} & $\begin{array}{l}\text { R: TCTTCCAGTGTTGCTTGTACC } \\
\text { F: TGAACATGAACTCTGCAACTCA }\end{array}$ & $(\mathrm{AGC})_{8}$ & 6 & $197-215$ & KU359009 \\
\hline & $\begin{array}{l}\text { R: GGCCACTATCCCATTAAAGCA } \\
\text { F. ACCCTGAAGCAAAGAAACCTC }\end{array}$ & (ATT) & 13 & $144-213$ & KU359010 \\
\hline $\mathrm{Se} 12$ & R: TCCACTCGACACCCTAGTTC & & & & \\
\hline
\end{tabular}

$N_{A}$ is the number of alleles found in 159 individuals from 5 colonies for each locus indicating few reproductives present in colonies on average. Finally, individuals within colonies were nearly as related as full siblings ( $r=0.469 \pm 0.019)$. Together, these analyses indicate that most of the study colonies had a breeding structure close to a simple family, although none of the colonies was a

Table 2 Alleles per locus found in reproductives of colony D

\begin{tabular}{lll}
\hline Locus & $\mathrm{N}_{\mathrm{A}}$ & Alleles \\
\hline Se1 & 6 & $107^{*}, 113,125,128,131$, and 134 \\
Se2 & 10 & $224,236,239,242,245,248,254^{*}, 260,263$, and 266 \\
Se3 & 5 & $173,176,179,185$, and 194 \\
Se4 & 5 & $163,166,175,193$, and 246 \\
Se5 & 7 & $212,215,224^{*}, 227^{*}, 230,233$, and 236 \\
Se6 & 8 & $199,202,205,208,220^{*}, 223,232$, and 289 \\
Se7 & 6 & $124,136,193,202,211$, and 217 \\
Se8 & 3 & 120,123, and 141 \\
Se9 & 6 & $173,176,179,182,200$, and 206 \\
Se10 & 4 & $129,132,135$, and 138 \\
Sel1 & 3 & 200,203, and $206^{*}$ \\
Se12 & 9 & $156^{*}, 162,165^{*}, 168,171,174,180,186$, and $204^{*}$ \\
\hline
\end{tabular}

$N_{A}$ number of alleles

*alleles exclusively found among the female neotenics simple family due to a small number of genotypes inconsistent with a single pair of parents. Colony D with 59 neotenics and an $F_{\mathrm{IC}}$ value of -0.0195 was an obvious exception to the pattern seen in the other four colonies.

The genotyped neotenics differed in size, with some females presenting advanced physogastry while others showed only a slightly swollen abdomen (Fig. 1). The allelic combination of these individuals did not differ from the physogastric neotenics, and this difference in size might be related to the nymphal instar of their origin.

\section{Mitochondrial DNA}

The fragment of COI region amplified was $620 \mathrm{bp}$ long, and the variation in the haplotypes occurred at positions 29,71 , $140,248,464,518,587$, and 590 in the gene sequences. We found three different haplotypes for COI within the five colonies of S. euamignathus. Colonies A and C shared haplotype I, whereas colonies B, D, and E shared haplotype II. Colony D, which had the multiple reproductives, presented two different haplotypes, one shared with colonies B and E (haplotype II) and another unique haplotype (haplotype III). Haplotype variation is summarized in Table 3. 
Table 3 Haplotype variation for COI found in the studied population of S. enamignathus

\begin{tabular}{cccccccccc}
\hline \multirow{2}{*}{ Colony } & \multicolumn{7}{c}{ Base Pair Position } & & $\begin{array}{c}\text { GeneBank } \\
\text { Accession } \\
\text { Number }\end{array}$ \\
\cline { 2 - 9 } & 29 & 71 & 140 & 248 & 464 & 518 & 587 & 590 & KU521793 \\
\hline $\mathrm{A}$ & $\mathrm{T}$ & $\mathrm{T}$ & $\mathrm{C}$ & $\mathrm{T}$ & $\mathrm{C}$ & $\mathrm{T}$ & $\mathrm{G}$ & $\mathrm{T}$ & KU521794 \\
\hline $\mathrm{B}$ & $\mathrm{T}$ & $\mathrm{C}$ & $\mathrm{T}$ & $\mathrm{C}$ & $\mathrm{T}$ & $\mathrm{C}$ & $\mathrm{G}$ & $\mathrm{C}$ & KUn \\
\hline $\mathrm{C}$ & $\mathrm{T}$ & $\mathrm{T}$ & $\mathrm{C}$ & $\mathrm{T}$ & $\mathrm{C}$ & $\mathrm{T}$ & $\mathrm{G}$ & $\mathrm{T}$ & KU521795 \\
\hline $\mathrm{D}$ & $\mathrm{T}$ & $\mathrm{C}$ & $\mathrm{T}$ & $\mathrm{C}$ & $\mathrm{T}$ & $\mathrm{C}$ & $\mathrm{G}$ & $\mathrm{C}$ & KU521796 \\
\hline $\mathrm{E}$ & $\mathrm{C}$ & $\mathrm{T}$ & $\mathrm{C}$ & $\mathrm{T}$ & $\mathrm{C}$ & $\mathrm{T}$ & $\mathrm{A}$ & $\mathrm{T}$ & KU521791 \\
\hline $\mathrm{E}$ & $\mathrm{T}$ & $\mathrm{C}$ & $\mathrm{T}$ & $\mathrm{C}$ & $\mathrm{T}$ & $\mathrm{C}$ & $\mathrm{G}$ & $\mathrm{C}$ & KU521792 \\
\hline
\end{tabular}

Haplotype I: light gray; haplotype II: white; haplotype III: dark gray

The occurrence of two haplotypes in colony $\mathrm{D}$ is indicative of at least two different females producing the neotenics. In addition, the occurrence of more than four alleles at specific loci, such as locus $\mathrm{Se} 2$ where we found ten alleles within the neotenics, suggests at least three different couples sharing haplotype II in the parental generation (Fig. 2). Depending on the loci, some alleles were exclusively present within the individuals of one or the other haplotype (Table 4).

\section{Discussion}

Independent colony foundation by unrelated queens was reported for $N$. corniger by Atkinson and Adams (1997). In this species, secondary reproductives may arise from pleometrotic associations, and this system leads to polycalism, in which a single colony headed by multiple unrelated reproductives is widespread among different nests ("calies"). Colonies with related reproductives occurred in single nests, while unrelated reproductives within a colony are allocated in different "calies". This later situation was described by Thorne (1982) as "voluntary" budding. In our case, a single nest of $S$. euamignathus, colony $\mathrm{D}$, contained 59 secondary reproductives belonging to at least two different matrilines. The results from the mtDNA analysis are in agreement with the microsatellite genotyping, which indicated that the neotenics originated from four or more primary couples. Both subgroups of neotenics from colony D sharing one or the other mtDNA haplotype presented more than four microsatellite alleles at a single locus, which suggests the presence of non-sibling reproductives in the previous generation. Of the five colonies sampled in this study, colony D was alone in this regard. Admittedly, it is possible that colony D was atypical, resulting from a set of highly unique circumstances and does not represent a common occurrence in S. enamignathus. However, given that we sampled only a small number of colonies, this possibility seems remote and it is likely that colonies with unrelated neotenics occur with some frequency in nature, at least in some populations.

The current scenario allows us to raise three hypotheses. First, two different female alates each mated with more than one male. This hypothesis unites the occurrence of pleometrotic colony foundation with a polyandry mating system by the co-founding females. Although this hypothesis seems to be the less probable because of the absence of known polyandry in primary reproductives in termites (Hartke and Baer 2011), a recent study by Wu et al. (2013) found evidence of polyandry in neotenics in the termite Reticulitermes labralis. These authors showed that one female neotenic mated with at least two male neotenics, as the alleles present in the offspring did not correspond to either asexual reproduction or
Fig. 2 Projection of the parental generation considering the two mtDNA haplotypes and the allelic variation $\left(A^{1-10}\right)$ found within the progeny at a single locus $(\mathrm{Se} 2)$

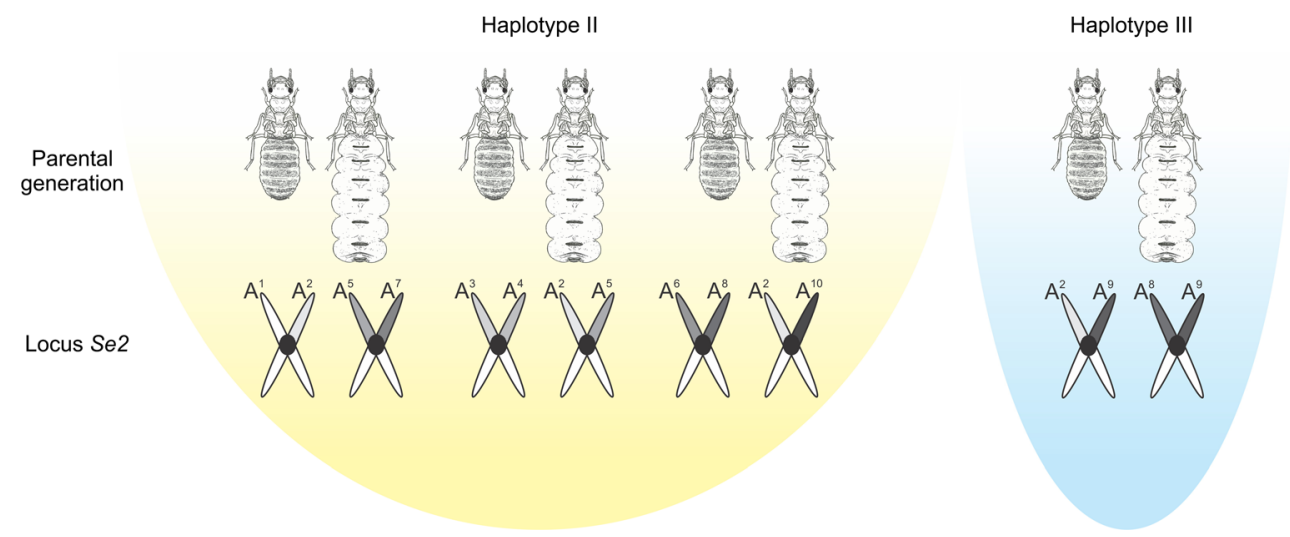


Table 4 Microsatellite loci genotypes of the 13 neotenics used for mtDNA haplotype analysis

\begin{tabular}{|c|c|c|c|c|c|c|c|c|c|c|c|c|c|c|c|c|c|c|c|c|c|c|c|c|}
\hline \multirow{4}{*}{$\begin{array}{l}\text { Neo } \\
\text { teni } \\
\text { cs }\end{array}$} & \multicolumn{24}{|c|}{ Microsatellite loci genotypes } \\
\hline & \multicolumn{2}{|c|}{ Se1 } & \multicolumn{2}{|c|}{$\mathrm{Se2}$} & \multicolumn{2}{|c|}{ Se3 } & \multicolumn{2}{|c|}{$\mathrm{Se} 4$} & \multicolumn{2}{|c|}{$\mathrm{Se5}$} & \multicolumn{2}{|c|}{ Se6 } & \multicolumn{2}{|c|}{$\mathrm{Se} 7$} & \multicolumn{2}{|c|}{$\mathrm{Se} 8$} & \multicolumn{2}{|c|}{ Se9 } & \multicolumn{2}{|c|}{ Se10 } & \multicolumn{2}{|c|}{$\mathrm{Se11}$} & \multicolumn{2}{|c|}{$\mathrm{Se} 12$} \\
\hline & $\mathrm{A}$ & $\mathrm{A}$ & $\mathrm{A}$ & $\mathrm{A}$ & $\mathrm{A}$ & $\mathrm{A}$ & $\mathrm{A}$ & $\mathrm{A}$ & $\mathrm{A}$ & $\mathrm{A}$ & A & A & $\mathrm{A}$ & $\mathrm{A}$ & $\mathrm{A}$ & A & $\mathrm{A}$ & $\mathrm{A}$ & $\mathrm{A}$ & A & $\mathrm{A}$ & $\mathrm{A}$ & $\mathrm{A}$ & A \\
\hline & 1 & 2 & 1 & 2 & 1 & 2 & 1 & 2 & 1 & 2 & 1 & 2 & 1 & 2 & 1 & 2 & 1 & 2 & 1 & 2 & 1 & 2 & 1 & 2 \\
\hline \multirow{3}{*}{$\begin{array}{c}\text { FN } \\
01\end{array}$} & 1 & 1 & 2 & 2 & 1 & 1 & 1 & 1 & 2 & 2 & 2 & 1 & 2 & 1 & 1 & 1 & 2 & 2 & 1 & 1 & 2 & 2 & 1 & 1 \\
\hline & 3 & 3 & 6 & 3 & 7 & 7 & 9 & 6 & 3 & 1 & 2 & 9 & 1 & 9 & 2 & 2 & 0 & 0 & 3 & 2 & 0 & 0 & 8 & 7 \\
\hline & 1 & 1 & 0 & 6 & 9 & 6 & 3 & 3 & 3 & 5 & 3 & 9 & 7 & 3 & 3 & 3 & 0 & 0 & 5 & 9 & 0 & 0 & 6 & 4 \\
\hline \multirow{3}{*}{$\begin{array}{c}\text { FN } \\
10\end{array}$} & 1 & 1 & 2 & 2 & 1 & 1 & 1 & 1 & 2 & 2 & 2 & 2 & 1 & 1 & 1 & 1 & 2 & 1 & 1 & 1 & 2 & 2 & 1 & 1 \\
\hline & 3 & 0 & 6 & 4 & 7 & 7 & 6 & 6 & 3 & 2 & 3 & 3 & 2 & 2 & 2 & 2 & 0 & 8 & 3 & 3 & 0 & 0 & 8 & 7 \\
\hline & 4 & 7 & 6 & 8 & 9 & 6 & 6 & 3 & 6 & 4 & 2 & 2 & 4 & 4 & 0 & 0 & 0 & 2 & 5 & 2 & 0 & 0 & 0 & 1 \\
\hline & 1 & 1 & 2 & 2 & 1 & 1 & 2 & 1 & 2 & 2 & 2 & 2 & 2 & 2 & 1 & 1 & 2 & 1 & 1 & 1 & 2 & 2 & 1 & 1 \\
\hline & 2 & 2 & 6 & 6 & 8 & 7 & 4 & 6 & 3 & 3 & 2 & 0 & 1 & 1 & 4 & 2 & 0 & 7 & 3 & 2 & 0 & 0 & 6 & 6 \\
\hline & 8 & 8 & 3 & 3 & 5 & 3 & 6 & 3 & 6 & 0 & 3 & 8 & 7 & 7 & 1 & 0 & 6 & 9 & 8 & 9 & 6 & 0 & 8 & 2 \\
\hline & 1 & 1 & 2 & 2 & 1 & 1 & 1 & 1 & 2 & 2 & 2 & 2 & 2 & 1 & 1 & 1 & 1 & 1 & 1 & 1 & 2 & 2 & 2 & 1 \\
\hline FN & 3 & 0 & 5 & 4 & 7 & 7 & 7 & 6 & 2 & 1 & 8 & 3 & 1 & 2 & 2 & 2 & 8 & 7 & 3 & 3 & 0 & 0 & 0 & 5 \\
\hline & 4 & 7 & 4 & 8 & 6 & 6 & 5 & 3 & 7 & 2 & 9 & 2 & 7 & 4 & 0 & 0 & 2 & 6 & 5 & 2 & 3 & 0 & 4 & 6 \\
\hline & 1 & 1 & 2 & 2 & 1 & 1 & 1 & 1 & 2 & 2 & 2 & 1 & 2 & 2 & 1 & 1 & 1 & 1 & 1 & 1 & 2 & 2 & 1 & 1 \\
\hline & 3 & 2 & 6 & 3 & 9 & 7 & 9 & 6 & 3 & 3 & 0 & 9 & 1 & 0 & 2 & 2 & 7 & 7 & 2 & 2 & 0 & 0 & 7 & 7 \\
\hline & 1 & 5 & 0 & 6 & 4 & 3 & 3 & 3 & 3 & 3 & 8 & 9 & 7 & 2 & 3 & 0 & 9 & 9 & 9 & 9 & 3 & 0 & 1 & 1 \\
\hline & 1 & 1 & 2 & 2 & 1 & 1 & 1 & 1 & 2 & 2 & 2 & 2 & 2 & 1 & 1 & 1 & 1 & 1 & 1 & 1 & 2 & 2 & 1 & 1 \\
\hline & 3 & 2 & 3 & 3 & 7 & 7 & 9 & 9 & 3 & 1 & 2 & 0 & 1 & 2 & 2 & 2 & 7 & 7 & 2 & 2 & 0 & 0 & 7 & 7 \\
\hline & 1 & 5 & 6 & 6 & 9 & 9 & 3 & 3 & 3 & 5 & 0 & 8 & 7 & 4 & 0 & 0 & 9 & 9 & 9 & 9 & 0 & 0 & 4 & 1 \\
\hline & 1 & 1 & 2 & 2 & 1 & 1 & 1 & 1 & 2 & 2 & 2 & 1 & 2 & 1 & 1 & 1 & 1 & 1 & 1 & 1 & 2 & 2 & 1 & 1 \\
\hline & 3 & 3 & 3 & 3 & 9 & 9 & 9 & 6 & 3 & 1 & 2 & 9 & 1 & 9 & 2 & 2 & 7 & 7 & 2 & 2 & 0 & 0 & 7 & 7 \\
\hline & 1 & 1 & 6 & 6 & 4 & 4 & 3 & 3 & 0 & 5 & 3 & 9 & 7 & 3 & 3 & 3 & 9 & 9 & 9 & 9 & 3 & 0 & 1 & 1 \\
\hline & 1 & 1 & 2 & 2 & 1 & 1 & 1 & 1 & 2 & 2 & 2 & 2 & 1 & 1 & 1 & 1 & 1 & 1 & 1 & 1 & 2 & 2 & 1 & 1 \\
\hline & 2 & 2 & 6 & 3 & 8 & 7 & 7 & 6 & 3 & 3 & 2 & 0 & 3 & 3 & 2 & 2 & 7 & 7 & 3 & 2 & 0 & 0 & 8 & 6 \\
\hline & 8 & 5 & 0 & 6 & 5 & 9 & 5 & 3 & 0 & 0 & 3 & 2 & 6 & 6 & 0 & 0 & 9 & 9 & 8 & 9 & 3 & 0 & 6 & 2 \\
\hline & 1 & 1 & 2 & 2 & 1 & 1 & 1 & 1 & 2 & 2 & 2 & 1 & 2 & 2 & 1 & 1 & 2 & 2 & 1 & 1 & 2 & 2 & 1 & 1 \\
\hline & 3 & 2 & 4 & 2 & 7 & 7 & 9 & 6 & 1 & 1 & 0 & 9 & 0 & 0 & 2 & 2 & 0 & 0 & 2 & 2 & 0 & 0 & 7 & 7 \\
\hline & 1 & 5 & 5 & 4 & 9 & 6 & 3 & 3 & 5 & 5 & 8 & 9 & 2 & 2 & 3 & 3 & 0 & 0 & 9 & 9 & 3 & 0 & 4 & 1 \\
\hline & 1 & 1 & 2 & 2 & 1 & 1 & 1 & 1 & 2 & 2 & 2 & 2 & 1 & 1 & 1 & 1 & 2 & 1 & 1 & 1 & 2 & 2 & 1 & 1 \\
\hline & 3 & 2 & 4 & 3 & 7 & 7 & 9 & 6 & 3 & 3 & 0 & 0 & 2 & 2 & 2 & 2 & 0 & 7 & 3 & 2 & 0 & 0 & 7 & 6 \\
\hline & 1 & 5 & 2 & 6 & 6 & 3 & 3 & 3 & 3 & 0 & 8 & 2 & 4 & 4 & 3 & 0 & 0 & 9 & 5 & 9 & 3 & 0 & 4 & 8 \\
\hline & 1 & 1 & 2 & 2 & 1 & 1 & 1 & 1 & 2 & 2 & 2 & 1 & 1 & 1 & 1 & 1 & 2 & 1 & 1 & 1 & 2 & 2 & 1 & 1 \\
\hline & 3 & 2 & 6 & 3 & 7 & 7 & 9 & 7 & 3 & 1 & 2 & 9 & 9 & 3 & 2 & 2 & 0 & 7 & 2 & 2 & 0 & 0 & 8 & 7 \\
\hline 18 & 1 & 5 & 0 & 6 & 9 & 9 & 3 & 5 & 3 & 5 & 3 & 9 & 3 & 6 & 3 & 0 & 0 & 9 & 9 & 9 & 3 & 0 & 6 & 1 \\
\hline & 1 & 1 & 2 & 2 & 1 & 1 & 1 & 1 & 2 & 2 & 2 & 2 & 2 & 2 & 1 & 1 & 2 & 1 & 1 & 1 & 2 & 2 & 1 & 1 \\
\hline & 2 & 1 & 4 & 3 & 7 & 7 & 7 & 6 & 3 & 3 & 0 & 0 & 0 & 0 & 2 & 2 & 0 & 7 & 3 & 3 & 0 & 0 & 7 & 6 \\
\hline 15 & 5 & 3 & 5 & 9 & 9 & 9 & 5 & 3 & 3 & 3 & 5 & 2 & 2 & 2 & 3 & 0 & 0 & 3 & 8 & 5 & 3 & 0 & 4 & 2 \\
\hline & 1 & 1 & 2 & 2 & 1 & 1 & 1 & 1 & 2 & 2 & 2 & 1 & 2 & 1 & 1 & 1 & 1 & 1 & 1 & 1 & 2 & 2 & 1 & 1 \\
\hline & 3 & 2 & 3 & 2 & 7 & 7 & 9 & 6 & 1 & 1 & 0 & 9 & 0 & 9 & 2 & 2 & 7 & 7 & 2 & 2 & 0 & 0 & 8 & 7 \\
\hline
\end{tabular}

The two haplotypes found within the neotenics from colony D is marked in white and dark gray in the neotenic code column. Alleles marked in yellow were exclusively found in individuals with mtDNA haplotype II (white) and those marked in blue in individuals with mtDNA haplotype III (dark gray). Alleles in bold were exclusively found in these individuals

$A 1$ and $A 2$ are alleles, $F N$ female neotenics, $D F N$ darker female neotenics, $M N$ male neotenics

sexual reproduction with a single male (simple family). As we did not have access to the parental generation because they were not present in the nest at the time of the collection, we cannot exclude this hypothesis.

The second hypothesis is that there is pleometrosis during colony foundation with multiple reproductive pairs, but only one male for each female. Pleometrotic associations were already recorded for the higher termites $N$. corniger (Thorne 1982, 1984; Atkinson and Adams 1997) and M. michaelseni (Hacker et al. 2005). In the latter species, the number of unrelated primary queens tends to decrease during the development of the colony, and few queens are likely to coexist in mature colonies. In this study, the genotyping results showed that at least four independent couples produced the 59 
secondary reproductives found in colony D. Three or more unrelated couples belonging to one maternal lineage generated some of the neotenic reproductives, and one or more unrelated couples belonging to another maternal lineage generated the other neotenics.

The third hypothesis is based on mixed families arising through colony fusion. Colony fusion often leads to the death of primary reproductives and the inheritance of the colony by replacement reproductives. Some termite species, mostly lower termites, exhibit colony fusion (DeHeer and Vargo 2004, 2008; Guaraldo and Costa-Leonardo 2009; Luchetti et al. 2013). Although there is no record of colony fusion for S. euamignathus, this termite often occupies abandoned nests of other termite species and restructures them (Rocha et al. 2012). This behavior indicates that either abandoned nests are colonized by alates after swarming or colonies have a certain mobility. Whether colonies are mobile and occupy nests built by conspecifics is difficult to know, because an inquiline colony would not need to modify the structure of a nest constructed by conspecifics. Indeed, no differences in nest shape and structure were observed among the colonies used in this study. The unique difference observed within the colonies was in respect to the nymphs, because all instars of the post-embryonic development were found in the colony with neotenics. Matsuura and Nishida (2001) reported that colony fusion in the termite Reticulitermes speratus is influenced by nymph ratios between the colonies. Whether the plenty of nymphs in the colony D was the key factor for colony fusion or a result of that, this scenario represents a disequilibrium of the colony reproductive system and, as suggested by Costa-Leonardo et al. (1999), the occurrence of multiple secondary reproductives would be a transitional situation after the disappearance of primaries in $S$. euamignathus, which is probable in the case of colony fusion.

Multiple secondary reproductives were also found by Barbosa et al. (2012) in a nest of Silvestritermes holmgreni without the primaries, suggesting that the occurrence of replacement reproductives may be widespread in the genus Silvestritermes. The female nymphoids of $S$. holmgreni also varied in size, and these differences were based on the instar of the nymph that differentiated into neotenics (Barbosa et al. 2012). Different degrees of physogastry were also found within female neotenics in S. euamignathus, which seem to be associated with the nymphal instar that differentiated into neotenics (Costa-Leonardo et al. 1999, Haifig et al., unpublished). In addition, we also collected the two darker reproductives that resemble nymph-imago-neotenic intercastes or pseudoimagos differentiating at a very late stage of the imaginal development, which may have appeared in response to orphaning of the colony, such as observed by Roisin and Pasteels (1986a, b) for Nasutitermes. Based on morphological characters, Rocha et al. (2012) pointed out in their taxonomic revision the close relationship between $S$. euamignathus and S. holmgreni, and the authors did not exclude the possibility of synonymy. As evidenced by morphology, the current scenario is still dubious and future genetic studies using the microsatellite markers developed here in colonies and populations of the genus Silvestritermes will provide a better understanding of the relationship among the species and the origin and relatedness of secondary reproductives in the group.

In sum, our results showed that colonies are often simple families in S. euamignathus and new colonies are likely to be founded by single couples. The occurrence of multiple reproductives in one of the colonies in this study, together with previous records of co-occurring multiple reproductives (Araujo 1958; Noirot 1956; Costa-Leonardo et al. 1996, 1998, 1999), indicates plasticity in the reproductive strategies in this termite species. The genetic analysis showed that the multiple secondary reproductives found within a colony were unrelated, indicating that they inherit a colony previously headed by unrelated reproductives. This is the first record of non-sibling neotenic reproductives in higher termites living within a single nest. Whether this reproductive condition is the result of pleometrotic colony foundation or colony fusion in S. euamignathus requires further investigation.

Acknowledgments The authors thank FAPESP (Process No. 2012/23898-0, 2014/00720-6 and 2014/25857-4) and CNPq (Process No. 305539/2014-0) for financial support. The authors also thank the four anonymous reviewers for their critical contributions.

\section{References}

Araujo RL (1958) Contribuição à biogeografia dos térmitas de São Paulo, Brasil (Insecta, Isoptera). Arq Inst Biol 25:185-217

Atkinson L, Adams ES (1997) The origins and relatedness of multiple reproductives in colonies of the termite Nasutitermes corniger. Proc R Soc Lond B 264:1131-1136

Barbosa JRC, Moura FMS, Bandeira AG, Vasconcellos A (2012) Caste differentiation pathways in the neotropical termite Armitermes holmgreni (Isoptera: Termitidae). Zool Sci 29:738-742

Coles-de-Negret HR, Redford K (1982) The biology of nine termite species (Isoptera: Termitidae) from the cerrado of Central Brazil. Psyche 89(1-2):81-106

Costa-Leonardo AM, Barsotti RC, Soares HX (1996) Multiple nymphoid reproductives in the nests of the neotropical termite, Armitermes euamignathus (Isoptera, Termitidae, Nasutitermitinae). Sociobiology 28(2):197-205

Costa-Leonardo AM, Soares HX, Barsotti RC (1998) Response to orphaning in two neotropical termites: Armitermes euamignathus and Embiratermes festivellus. Entomol Exp Appl 88:109-114

Costa-Leonardo AM, Barsotti RC, Soares HX (1999) Morphology of the nymphoid replacement reproductives in the neotropical termite Armitermes euamignathus (Isoptera, Termitidae, Nasutitermitinae). J Morphol 239(2):131-141

DeHeer CJ, Vargo EL (2004) Colony genetic organization and colony fusion in the termite Reticulitermes flavipes as revealed by foraging patterns over time and space. Mol Ecol 13:431-441 
DeHeer CJ, Vargo EL (2008) Strong mitochondrial DNA similarity but low relatedness at microsatellite loci among families within fused colonies of the termite Reticulitermes flavipes. Insect Soc 55:190 199

Fougeyrollas R, Dolejšová K, Sillam-Dussès D, Roy V, Poteaux C, Hanus R, Roisin Y (2015) Asexual queen succession in the higher termite Embiratermes neotenicus. Proc R Soc Lond B 282: 20150260

Goudet J (2002) FSTAT, a program to estimate and test gene diversities and fixation indices

Guaraldo AC, Costa-Leonardo AM (2009) Preliminary fusion testing between whole young colonies of Coptotermes gestroi (Isoptera: Rhinotermitidae). Sociobiology 53:767-774

Hacker M, Kaib M, Bagine RKN, Epplen JT, Brandl R (2005) Unrelated queens coexist in colonies of the termite Macrotermes michaelseni. Mol Ecol 14:1527-1532

Hartke TR, Baer B (2011) The mating biology of termites: a comparative review. Anim Behav 82(5):927-936

Hartke TR, Rosengaus RB (2013) Costs of pleometrosis in a polygamous termite. Proc R Soc Lond B Biol Sci 280:20122563

Koressaar T, Remm M (2007) Enhancements and modifications of primer design program Primer3. Bioinformatics 23(10):1289-91

Luchetti A, Dedeine F, Velonà A, Mantovani B (2013) Extreme genetic mixing within colonies of the wood-dwelling termite Kalotermes flavicollis (Isoptera, Kalotermitidae). Mol Ecol 22:3391-3402

Mathews AG (1977) Studies on termites from the Mato Grosso state, Brazil. Academia Brasileira de Ciências, Rio de Janeiro, p 267

Matsuura K, Nishida T (2001) Colony fusion in a termite: what makes the society "open"? Insect Soc 48:378-383

Matsuura K, Vargo EL, Kawatsu K, Labadie PE, Nakano H, Yashiro T, Tsuji K (2009) Queen succession through asexual reproduction in termites. Science 323:1687

Miller LR (1969) Caste differentiation in the lower termites. In: Biology of Termites. Krishna K, Weesner FM (eds) pp. 283-310

Myles TG (1999) Review of secondary reproduction in termites (Insecta: Isoptera) with comments on its role in termite ecology and social evolution. Sociobiology 33:1-91

Noirot C (1956) Les sexués de remplacement chez les termites supérieurs (Termitidae). Insect Soc 3:145-148
Noirot C (1969) Formation of castes in higher termites. In: Biology of Termites. Krishna K, Weesner FM (eds) pp. 311-350

Rocha MM, Cancello EM, Carrijo TF (2012) Neotropical termites: revision of Armitermes Wasmann (Isoptera, Termitidae, Syntermitinae) and phylogeny of the Syntermitinae. Syst Entomol 37:793-827

Roisin Y, Pasteels JM (1985) Imaginal polymorphism and polygyny in the Neo-Guinean termite Nasutitermes princeps (Desneux). Insect Soc 32:140-157

Roisin Y, Pasteels JM (1986a) Replacement of reproductives in Nasutitermes princeps (Desneux) (Isoptera: Termitidae). Behav Ecol Sociobiol 18:437-442

Roisin Y, Pasteels JM (1986b) Differentiation of worker-derived intercastes and precocious imagoes after queen removal in the NeoGuinean termite Nasutitermes princeps (Desneux). J Morphol 189: 281-293

Thorne BL (1982) Polygyny in termites: multiple primary queens in colonies of Nasutitermes corniger (Motschulsky) (Isoptera: Termitidae). Insect Soc 29:102-117

Thorne BL (1984) Polygyny in the neotropical termite Nasutitermes corniger: life history consequences of queen mutualism. Behav Ecol Sociobiol 14:117-136

Thorne BL, Breisch NL, Muscedere ML (2003) Evolution of eusociality and the soldier caste in termites: influence of intraspecific competition and accelerated inheritance. Proc Natl Acad Sci 100(22): 12808-12813

Untergrasser A, Cutcutache I, Koressaar T, Ye J, Faircloth BC, Remm M, Rozen SG (2012) Primer3 - new capabilities and interfaces. Nucleic Acids Res 40(15):e115

Vargo EL, Husseneder C (2011) Genetic structure of termite colonies and populations. In: Biology of Termites: a modern synthesis. Bignell DE, Roisin Y, Lo N (eds) pp. 321-347

Vargo EL, Labadie PE (2012) Matsuura K (2012) Asexual queen succession in the subterranean termite Reticulitermes virginicus. Proc $\mathrm{R}$ Soc B Biol Sci 279(1729):813-819

Wu J, Su X, Kong X, Liu M, Xing L (2013) Multiple male and female reproductive strategies and the presence of a polyandric mating system in the termite Reticulitermes labralis (Isoptera: Rhinotermitidae). Sociobiology 60(4):459-465

Ye C, Ma ZS, Cannon CH, Pop M, Yu DW (2012) Exploiting sparseness in de novo genome assembly. BMC Bioinformatics 13(Suppl 6):S1 